\title{
Klasifikasi Resiko Kerusakan Lahan Akibat Tsunami Menggunakan Citra Landsat 8 Di Kabupaten Bantul
}

\author{
Ellen Yumanda ${ }^{* 1}$, Magdalena A. Ineke Pakereng ${ }^{2}$ \\ ${ }^{1,2} \mathrm{Jl}$. Diponegoro 52-60, Salatiga 50711, Indonesia ${ }^{3} J u r u s a n$ Teknik Informatika, \\ FTI UKSW, Salatiga \\ e-mail : ${ }^{1} 672017270 @$ student.uksw.edu, ${ }^{2}$ ineke.pakereng@uksw.edu
}

\begin{abstract}
Abstrak
Tsunami ialah musibah alam yang membagikan ancaman serta kehancuran cukup besar di Indonesia disebabkan separuh dari daerah di indonesia merupakan lautan. Indonesia mengalami tsunami besar sudah beberapa kali. Riset ini dibuat untuk mengenali daerah mana saja yang mempunyai resiko kerusakan lahan paling tinggi serta paling rendah, riset dilakukan dengan tatacara Machine Learning serta algoritma ANN. Informasi yang digunakan dalam riset ini merupakaninformasi citra satelit yang diambil dari tahun 2013 - 2020 dengan daerah riset di kabupaten Bantul yang terdiri dari 72 desa. Riset ini memakai indeks vegetasi dari band citra satelit, indeks vegetasi yang akan digunakan antara lain NDVI, NDWI, NDBI, MNDWI, SAVI. Algoritma ANN memberikan hasil yang cukup akurat dengan tingkat akurasi sebesar 95.45\%, dan nilai Kappa sebesar 87.91\%. Prediksi menyatakan bahwa sebagian desa di kabupaten Bantul yang memiliki resiko kerusakan tinggi akibat tsunami yaitu desa Banguntapan, Bangunjiwo, Ringinharjo, Imogiri, Tirtonirmolo.
\end{abstract}

Kata kunci: Tsunami, Indeks Vegetasi, ANN.

Abstract
Tsunami is a natural disaster that poses a large enough threat and destruction in Indonesia because half of the area in Indonesia is ocean. Indonesia has experienced major tsunamis several times. This research was made to identify which areas have the highest and lowest risk of land damage, the research was carried out using Machine Learning and ANN algorithms. The information used in this research is satellite image information taken from 2013 - 2020 with the research area in Bantul district which consists of 72 villages. This research uses a vegetation index from satellite imagery bands, the vegetation indices to be used include NDVI, NDWI, NDBI, MNDWI, SAVI. The ANN algorithm gives fairly accurate results with an accuracy rate of $95.45 \%$, and a Kappa value of $87.91 \%$. The prediction states that some villages in Bantul district that have a high risk of damage due to the tsunami are Banguntapan, Bangunjiwo, Ringinharjo, Imogiri, Tirtonirmolo villages.

Keywords: Tsunami, Vegetasi Index, ANN.

\section{PENDAHULUAN}

Indonesia ialah negeri kepulauan terbanyak di dunia. Terbentang dari Sabang sampai Merauke,Indonesia mempunyai 17.499 pulau dengan luas total daerah Indonesia 7,81 juta km2. Dari total luas daerah tersebut 3,25 juta $\mathrm{km} 2$ merupakan lautan serta 2,55 juta km2 merupakan Zona Ekonomi Eksklusif. Hanya 2.01 juta km2 yang berbentuk daratan. Dengan luas daerah 
lautan terbanyak menjadikan Indonesia mempunyai ancaman musibah akan terjadinya bencana alam tsunami juga besar. Tsunami ialah salah satu ancaman musibah buat daerah pesisir di Indonesia. Musibah ini biasanya terjadi karena terbentuknya gempa bumi di laut yang menimbulkan pergerakan secara vertikal di dasar laut. Bersumber pada catatan sejarah, tsunami bukan bencana baru dalamkehidupan penduduk di Indonesia semenjak tahun 1600 hingga tahun 2007, beberapa kali tsunami besar sudah terjadi di Indonesia. Dalam jangkauan waktu itu Indonesia telah mengalami musibah tsunami kurang lebih 172 kali [1]. Berdasarkan latar belakang yang ada maka hendak dilakukan penelitian untuk melakukan klasifikasi ataupun prediksi resiko kerusakan lahan yang diakibatkan tsunami menggunakan citra satelit dengan Machine Learning dan dengan metode Artificial Neural Network dan akan dibandingkan dengan metode SVM, Random Forest, Nä̈ve Bayes. Daerah yangmenjadi penelitian ini yaitu Kabupaten Bantul yang memiliki 72 desa. Analisis ini menggunakan indeks vegetasi NDVI, NDWI, NDBI, MNDWI, SAVI. Hasil penelitian yang diperoleh dapat dijadikan data untuk mengenali daerah yang mengalami resiko kerusakan tinggi ataupun rendah akibat tsunami sehingga dapat membagikan kemudahan dalam memastikan tindakan yang efektif dalam mendapati musibah tsunami.

Pada penelitian terdahulu yang berjudul " Pemanfaatan Teknologi Machine Learning Untuk Klasifikasi Wilayah Risiko Kekeringan di Daerah Istimewa Yogyakarta Menggunakan Citra Landsat 8 Operational Land Imager (OLI)", menjelaskan bahwa dengan menggunakan Citra Landsat 8 untuk mengklasifikasikan wilayah risiko kekeringan dan mendapatkan hasil klasifikasi wilayah resiko ini memiliki hasil akurasi sebesar $93.88 \%$ menggunakan algoritma ANN [2]. Padapenelitian terdahulu yang berjudul " Analisis Index Vegetasi Pesisir Pantai Aceh Pasca Tsunami Menggunakan Citra Satelit Landsat 7 dan Landsat 8 Dengan Metode Clustering Algoritma $K$-Means", menjelaskan tentang analisis NDVI wilayah pesisir pantai Aceh dengan membandingkan hasil Analisis Indeks Vegetasi Aceh pada saat sebelum, setelah terjadi bencana Tsunami dan keadaan saat ini dengan menggunakan metode Clustering K-Means. Hasil analisis menunjukkan bahwa sebelum dan sesuah terjadinya gempa tahun 2004 itu mempunyai perbedaan yaitu pada wilayah kabupaten Aceh Barat Daya memiliki luas hutan dan daerah pemukiman disertai garis pantai yang sangat baik namun ketika gempa pada tahun 2005 ini terjadi pelebaran lahan vegetasi dan pemukiman yang begitu besar karena adanya perubahan lahan tandus dan bebatuan yang menjadi lahan hijau [3]. Pada penelitian terdahulu yang berjudul "Analisis Indeks Vegetasi Area Terdampak Banjir Bandang Di Kabupaten Jayapura Menggunakan Metode Clustering Pada Citra Landsat 8", menjelaskan bahwa Citra Landsat 8 memberikan hasil perbandingan dari indeks vegetasi yang terdiri dari: Lahan Hijau, Lahan Terbuka, Air, Bebatuan, Tanah dan dari segi pemukiman dan bangunan sebelum dan sesudah terkena banjir bandang. Hasilnya menunjukkan bahwa terjadi penurunan pada area pemukiman atau bangunan, lahan terbuka bebatuan, dan air, sedangkan di lahan hijau tidak mengalami perubahan [4].

\section{METODE PENELITIAN}

Metode penelitian yang digunakan dalam penelitian yang dilakukan, dijelaskan sebagai berikut. Lokasi atau wilayah penelitian berada di Kabupaten Bantul. 


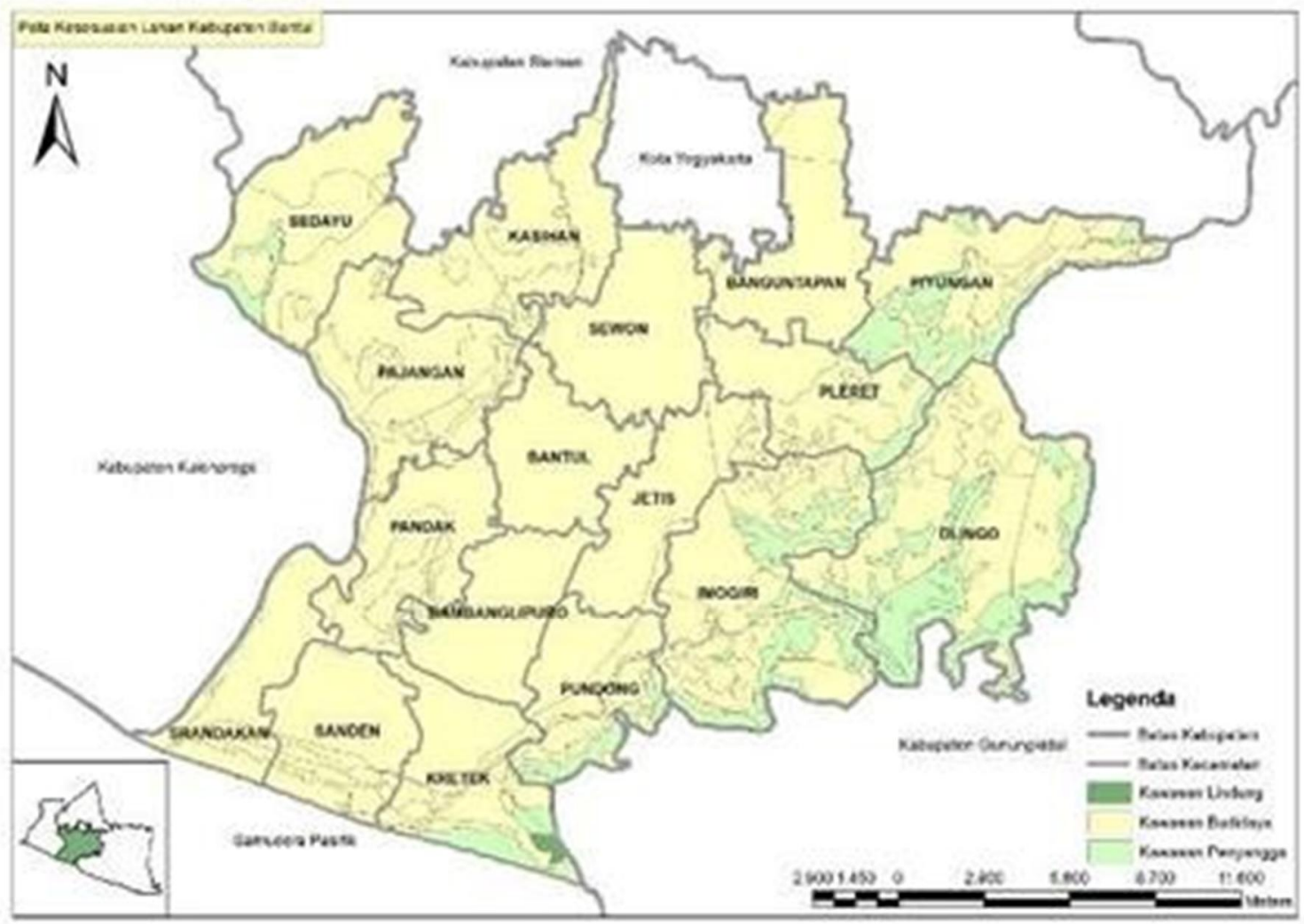

Gambar 1. Wilayah Penelitian Kabupaten Bantul

Gambar 1 merupakan wilayah penelitian yang berada di Kabupaten Bantul. Kabupaten Bantul ialah salah satu kabupaten yang terletak di Daerah Istimewa Yogyakarta. Kabupaten Bantul berbatasan dengan kota Yogyakarta serta Kabupaten Sleman di sebelah utara, dan Kabupaten Gunung Kidul di sebelah timur, Samudra Hindia di sebelah selatan, dan Kabupaten Kulon Progo di sebelah barat. Kabupaten Bantul terletak pada koordinat 7. 88461 ${ }^{\circ} \mathrm{S} 110$. $33411^{\circ}$ E. Data yang akandigunakan dalam penelitian ini yaitu data Citra Landsat 8 dari 72 desa di Kabupaten Bantul dari tahun 2013-2020 yang diambil dari web https:// earthexplorer. usgs. gov/.

Satelit pemantau bumi ini mempunyai 2 (dua) sensor ialah Operational Land Imager (OLI) serta Thermal Infrared Sensor (TIRS), sensor ini memiliki resolusi spesial $30 \mathrm{~m}$ (Visible, NIR, SWIR) $100 \mathrm{~m}$ (Thermal) serta $15 \mathrm{~m}$ (pankromatik). Pada sensor OLI mempunyai 8 band ialah band 1 Coastal, band 2 Blue, band 3 Green, band 4 Red, band 5 Near-Infrared, band 6 SWIR- 1, band 7 SWIR- 2, band Pankromatik serta band Cirrus. Sebaliknya di sensor TIRS hanya mempunyai 2 band ialah band 10 TIRS serta band 11 TIRS. Riset ini menggunakan 4 tipe band ialah band 3 Green, band 4 Red, band 5 Near-infrared, band 6 SWIR- 1. 


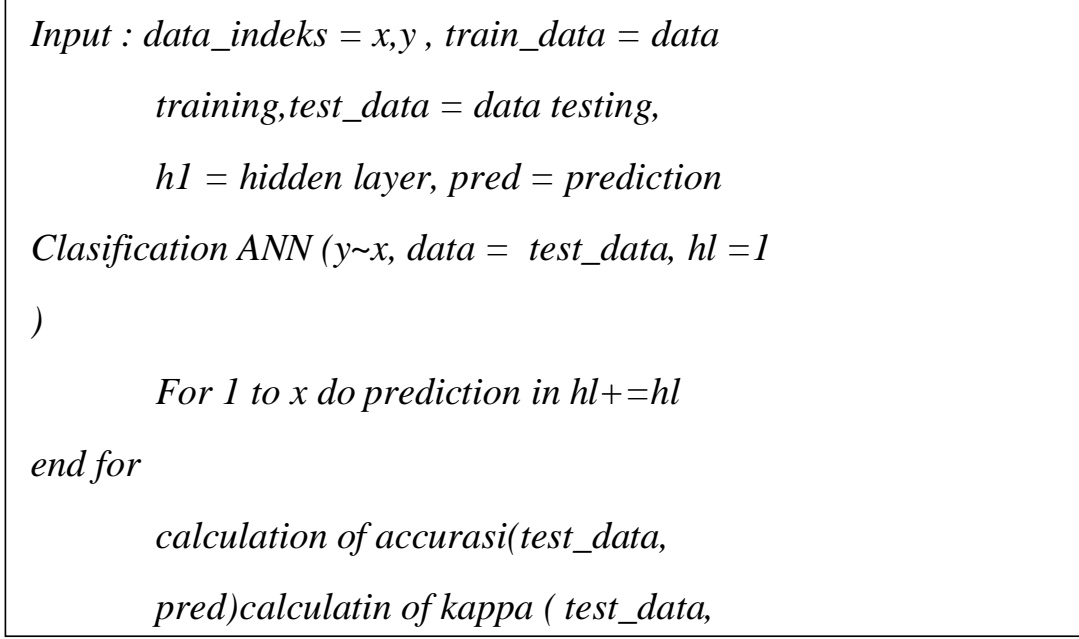

Gambar 2. Pseudocode Klasifikasi dan Prediksi

Gambar 2 menunjukkan pseudocode klasifikasi dan prediksi, yang menjelaskan tentang struktur proses klasifikasi dan prediksiyang dilakukan dalam penelitian ini. Pengolahan data secara garis besar dibagi jadi 3 (tiga) tahapan yakni :

1) Pengolahan data citra yang telah ada antara lain:

a. Koreksi radiomatrik, koreksi geomatric, koreksi atmosferik.

b. Pengolahan indeks Ndvi, Ndbi, Ndwi, Mndwi, serta Savi dengan mengkombinasikan bandagar menghasilkan indeks berbentuk angka.

2) Klasifikasi serta prediksi data yang telah didapatkan dengan $75 \%$ data digunakan untuk data training serta $25 \%$ data digunakan untuk data testing menggunakan metode ANN serta metode SVM, Random Forest serta Nä̈ve Bayes untuk membuat perbandingan tingkat akurasi serta nilai kappa.

3) Hasil metode ANN didistribusikan menggunakan IDW serta memvisualisasikan hasil jadi peta persebaran daerah dengan kerusakan lahan akibat tsunami tinggi serta rendah. 


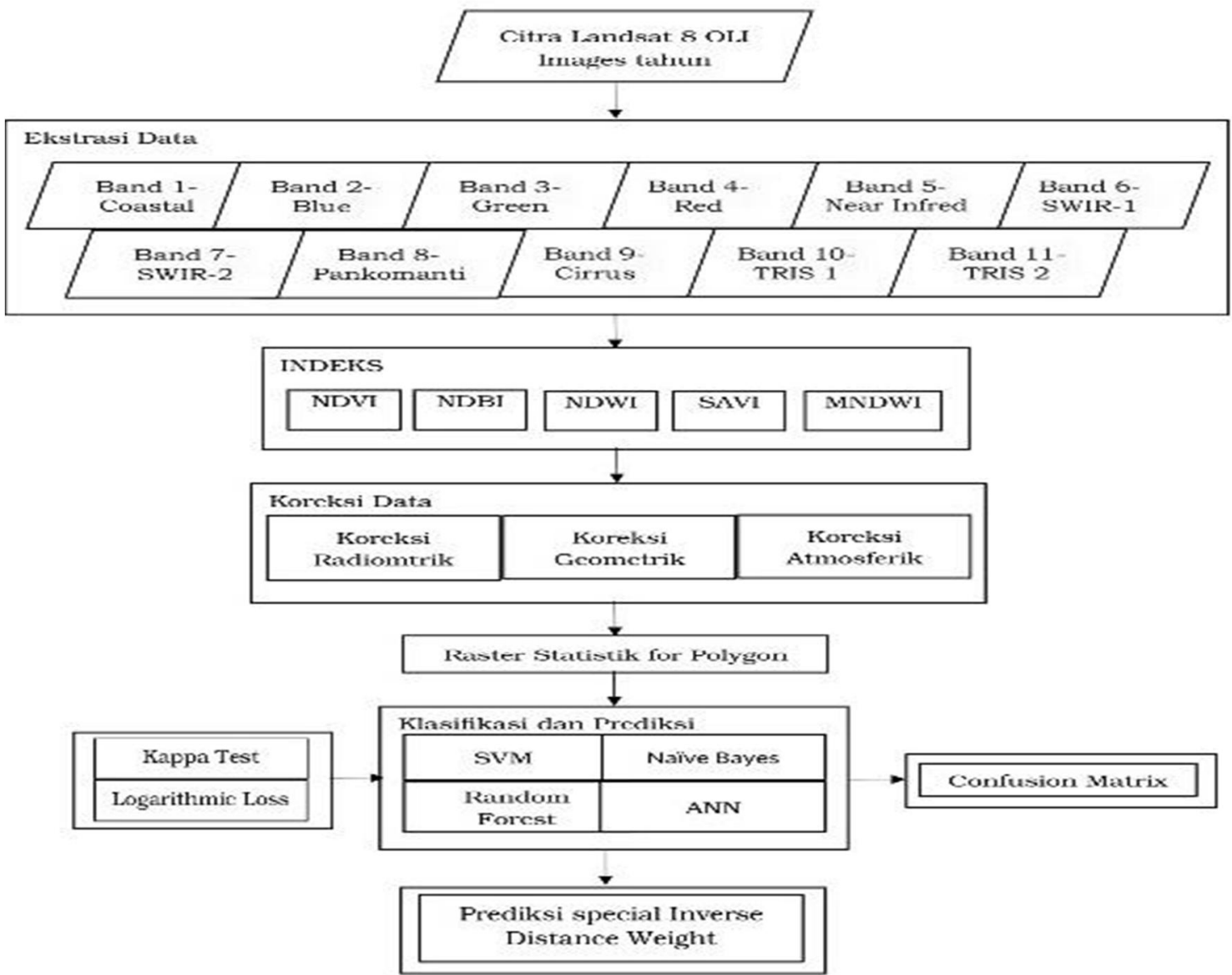

Gambar 3. Metode Penelitian

Indeks vegetasi ialah suatu perumusan pengolahan data inderaja secara digital yang dapat ditunjukkan secara spesial guna mengkaji data tematik dari lahan yang bervegetasi ( Carolita, 1995). Sebagian indeks vegetasi yang diperlukan dalam penelitian ini ialah NDVI, NDBI, MNDWI, NDWI, serta SAVI.

a. NDVI

Normalized Difference Vegetation Index (NDVI) ialah indeks yang kerap digunakan untuk menyamakan tingkatan kehijauan vegetasi (tingkatan klorofil) pada tanaman dengan Persamaan 1[5]. Klasifikasi nilai NDVI ditunjukkan pada Tabel 1.

$$
N D V I=\frac{N I R-R E D}{N I R+R E D}=\frac{\text { Band } 5-B \text { and } 4}{\text { Band } 5+\text { Band } 4}
$$

Tabel 1. Klasifikasi Nilai NDVI

\begin{tabular}{ccc}
\hline Kelas & Nilai NDVI & Klasifikasi \\
\hline 1 & $-1 \mathrm{~s} / \mathrm{d}-0.03$ & Lahan Tidak Bervegetasi \\
2 & $-0.03 \mathrm{~s} / \mathrm{d} 0.15$ & Tingkat Kehijauan Sangat Rendah \\
3 & $0.15 \mathrm{~s} / \mathrm{d} 0.25$ & Tingkat Kehijauan Rendah \\
4 & $0.26 \mathrm{~s} / \mathrm{d} 0.35$ & Tingkat Kehijauan Sedang \\
5 & $0.36 \mathrm{~s} / \mathrm{d} 1.00$ & Tingkat Kehijauan Tinggi \\
\hline
\end{tabular}




\section{b. NDBI}

Normalized Difference Bult- up Index( NDBI) merupakan indeks lahan terbangun ialah sesuatu algoritma buat memastikan kerapatan lahan terbangun dengan Persamaan 2 [6]. Klasifikasi niali NDBI ditunjukkan pada Tabel 2.

$$
N D B I=\frac{S W I R-N I R}{S W I R+N I R}=\frac{\text { Band } 6-\text { Band } 5}{\text { Band } 6+\text { Band } 5}
$$

Tabel 2. Klasifikasi Nilai NDBI

\begin{tabular}{|c|l|l|}
\hline Kelas & \multicolumn{1}{|c|}{ Nilai NDBI } & \multicolumn{1}{c|}{ Klasifikasi } \\
\hline 1 & $-1 \mathrm{~s} / \mathrm{d} 0$ & Non Pemukiman \\
\hline 2 & $0 \mathrm{~s} / \mathrm{d} 0.1$ & Pemukiman Jarang \\
\hline 3 & $0.1 \mathrm{~s} / \mathrm{d} 0.2$ & Pemukiman rapat \\
\hline 4 & $0.2 \mathrm{~s} / \mathrm{d} 0.3$ & Pemukiman sangat rapat \\
\hline
\end{tabular}

c. NDWI

Normalized Difference Water Index( NDWI) ialah indeks yang menekankan pada kebasahanvegetasi dengan Persamaan 3 [7]. Klasifikasi nilai NDWI ditunjukkan pada Tabel 3

$$
N D W I=\frac{G R E E N-N I R}{\text { GREEN+NIR }}=\frac{\text { Band } 3-\text { Band } 5}{\text { Band } 3+\text { Band } 5}
$$

Tabel 3. Klasifikasi Nilai NDWI

\begin{tabular}{|c|l|l|}
\hline Kelas & \multicolumn{1}{|c|}{ Nilai NDWI } & \multicolumn{1}{|c|}{ Klasifikasi } \\
\hline 1 & $-0.732996 \mathrm{~s} / \mathrm{d} 0$ & Non-Badan Air \\
\hline 2 & $0 \mathrm{~s} / \mathrm{d} 0.33$ & Kebasahan Sedang \\
\hline 3 & $0.33 \mathrm{~s} / \mathrm{d} 1$ & Kebasahan Tinggi \\
\hline
\end{tabular}

\section{d. MNDWI}

Modified Normalize Difference Water Index( MNDWI) ialah modified dari NDWI yangdigunakan untuk penegasan batasan daratan dan lautan dengan Persamaan 4 [8].

$$
M N D W I=\frac{G R E E N-S W I R}{G R E E N+S W I R}=\frac{\text { Band } 3-\text { Band } 6}{\text { Band } 3+\text { Band } 6}
$$

\section{e. SAVI}

Soil Adjusted Vegetation Index( SAVI) ialah algoritma pengembangan dari NDVI dan dengan menekan latar belakang tanah pada tingkatan kecerahan kanopi dengan menggunakan Persamaan 5 [9]. Klasifikasi nilai SAVI ditunjukkan pada Tabel 4.

$$
S A V I=(1+L) * \frac{N I R-R E D}{N I R+R E D}=\frac{\text { Band } 5-\text { Band } 4}{\text { Band } 5-\text { Band } 4}
$$

Tabel 4. Klasifikasi Nilai SAVI

\begin{tabular}{|l|l|l|}
\hline \multicolumn{1}{|c|}{ Kelas } & \multicolumn{1}{|c|}{ Kerapatan } & \multicolumn{1}{c|}{ Jenis RTH } \\
\hline$-0.3667 \mathrm{~s} / \mathrm{d} 0.0187$ & Non RTH & Tubuh air seperti sungai \\
\hline $0,0187 \mathrm{~s} / \mathrm{d} 0.1041$ & Sangat Rendah & $\begin{array}{l}\text { Pemukiman lahan terbuka yang dilapisi dengan } \\
\text { aspal atau paving maupun jalan aspal }\end{array}$ \\
\hline $0.1041 \mathrm{~s} / \mathrm{d} 0.3667$ & Rendah & $\begin{array}{l}\text { Lahan vegetasi penutup tanah, seperti pada } \\
\text { jalan tanah, lapangan kosong tanpa dilapisiaspal } \\
\text { atau paving }\end{array}$ \\
\hline $0.3667 \mathrm{~s} / \mathrm{d} 0.5214$ & Sedang & Lahan vegetasi penutup berupa perkebunan \\
\hline
\end{tabular}




\begin{tabular}{|l|l|l|}
\hline & & $\begin{array}{l}\text { kelapa, kebun campuran. Vegetasi rerumputan, } \\
\text { padang golf, alang alang }\end{array}$ \\
\hline $0.5214 \mathrm{~s} / \mathrm{d} 0.7895$ & Tinggi & Vegetasi Berhutan \\
\hline
\end{tabular}

Data dari hasil indeks vegetasi yang telah diolah kemudian dikelompokkan sesuai dengan klasifikasi yang telah ditetapkan serta akan diolah untuk melakukan tahapan klasifikasi dan prediksi dengan metode ANN, Random Forest, Support Vector Machine dan Nä̈ve Bayes. Metode ANN dengan formula ialah input layer, hidden layer, dan output layer merupakan klasifikasi dan prediksi dengan meniru perilaku biologis syaraf. Hasil klasifikasi dan prediksi yang telah didapatkan menggunakan metode ANN akan dianalisis dengan pendekatan Kappa untuk melihat validasi dan realibitas hasil dari penelitian Nilai interpretasi Kappa disajikan pada Tabel 5.

Tabel 5. Interpretasi Kappa

\begin{tabular}{|l|l|}
\hline Kappa & Klasifikasi \\
\hline$<0.40$ & Bad \\
\hline $0.40-0.60$ & Fair \\
\hline $0.60-0.75$ & Good \\
\hline$>0.75$ & Excellent \\
\hline
\end{tabular}

Distribusi indeks vegetasi menggunakan interpolasi Inverse Distance Weighted (IDW) untuk menentukan wilayah kerusakan yang disebabkan oleh tsunami. Metode ini menggunakan data rata-rata dari sampel sehingga hasil nilai yang didapatkan tidak lebih besar atau kecil dari minimal atau lebih besar dari data sampel, dengan Persamaan 6.

$$
Z=\sum_{i=1}^{N} w_{i} Z_{i}
$$

Dimana $z_{i}(\mathrm{I}=1,2,3 \ldots \mathrm{N})$ merupakan nilai ketinggian data yang ingin diinterpolasi sejumlahN titik, dan bobot (weight) $w_{i}$ dengan Persamaan 7.

$$
w_{i}=\frac{\frac{h_{i}^{-p}}{i}}{\sum_{j}^{n} h_{j}^{p}}
$$

$\mathrm{p}$ adalah nilai nilai positif yang dapat diubah-ubah yang disebut dengan parameter power (biasanya bernilai 2) dan $h_{j}$ merupakan jarak dari sebaran titik ke titik interpolasi dengan Persamaan 8.

$$
h_{i}=\sqrt{\left(x-x_{i}\right)^{2}+\left(y-y_{i}\right)^{2}}
$$

$(\mathrm{x}, \mathrm{y})$ adalah koordinat titik interpolasi dan $\left(x_{i}, y_{i}\right)$ yaitu koordinat untuk setiap sebaran titik. Fungsi peubah weight bervariasi untuk keseluruhan data sebaran titik sampai pada nilai yang mendekati nol dimana jarak bertambah terhadap sebaran titik [10].

\section{HASIL PEMBAHASAN}

Data yang digunakan dalam penelitian ialah hasil dari kombinasi band indeks vegetasi selama 8 tahun yakni dari tahun 2013- 2020. Dalam mengolah data dilakukan analisis korelasi guna mengetahui hubungan antar indeks dengan mengkategorikan berdasarkan kerusakan wilayah tinggi atau rendah akibat tsunami 


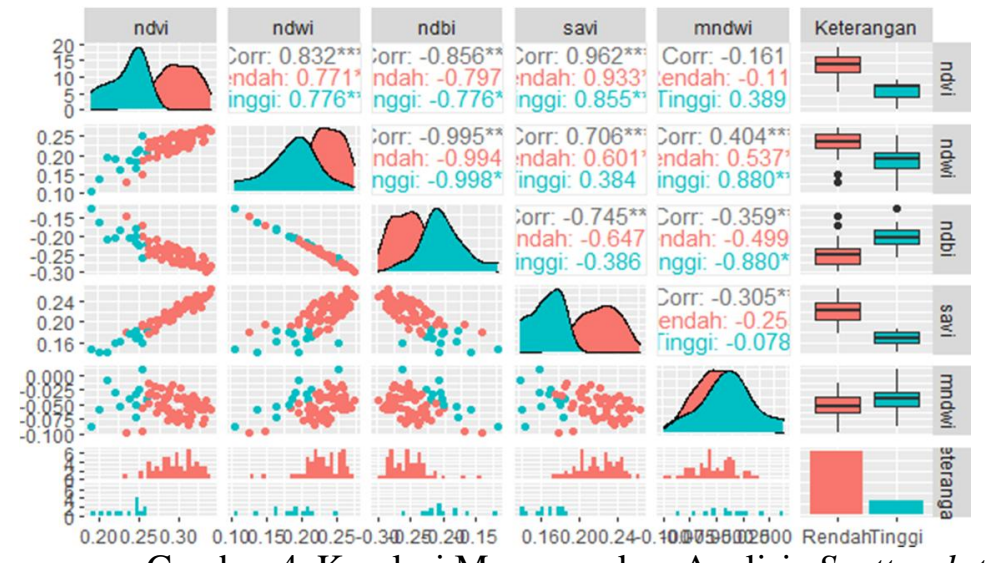

Gambar 4. Korelasi Menggunakan Analisis Scatterplot.

Analisi Scatterplot yang ditunjukkan pada Gambar 4 ialah hubungan antara indeks vegetasi yangmemiliki hubungan korelasi yang positif dan negatif. Hubungan antara NDVI dan SAVI merupakan hubungan korelasi positif dan mempunyai nilai paling tinggi yaitu 0,962 , nilai kerusakan rendah sebesar 0,855 dan nilai kerusakan tinggi sebesar 0.933. sedangkan hubungan antara NDWI dan NDBI merupakan korelasi paling rendah sebesar -0,995, dengan nilai kerusakanrendah sebesar -0.994 dan kerusakan tinggi sebesar -0,998.

Setelah itu akan dilakukan klasifikasi menggunakan algoritma ANN dan dengan R Studio dan jumlah hidden layer 1 untuk mendapatkan akurasi penggunaan algoritma ANN yang terbaik agar dapat digunakan dalam klasifikasi atau perdiksi data.

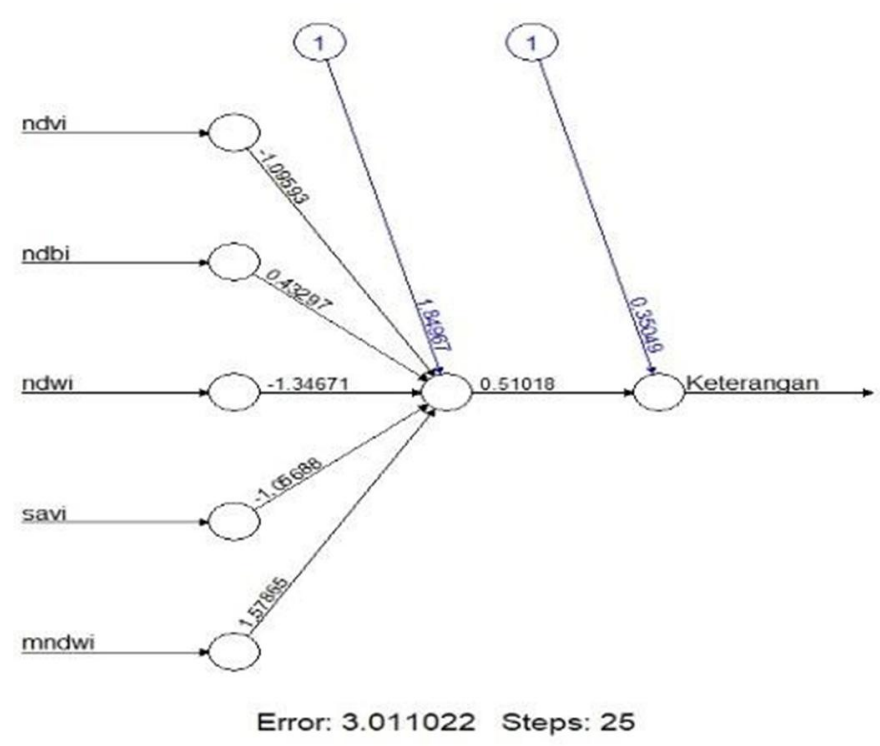

Gambar 5. Jaringan Hasil Prediksi ANN

Berdasarkan Gambar 5 terdapat 5 (lima) input yaitu ndvi, ndbi, ndwi, savi, mndwi dapat dilihat bahwa hasil prediksi menunjukkan adanya error sebanyak 3.011022 dan melakukan 25 langkah. Prediksi ini dilakukan dan 8 tahun belakang dilakukan dengan algoritma ANN dengan menggunakan hidden layer 1 . Hasil dari rata-rata indeks selama kurang lebih 8 tahun menghasilkan beberapa desa yang masuk dalam kerusakan lahan tinggi dikarenakan tsunami, yang ditunjukkan pada Tabel 6.

Ellen, et., al [Klasifikasi Resiko Kerusakan Lahan AkibatTsunami Menggunakan Citra Landsat 8 
Tabel 6. Hasil Prediksi Kerusakan Wilayah Akibat Tsunami Tinggi

\begin{tabular}{|c|c|c|}
\hline Desa & Kecamatan & Nilai \\
\hline Banguntapan & Banguntapan &, 860139035 \\
\hline Bangunjiwo & Kasihan &, 860128674 \\
\hline Ringinharjo & Bantul &, 860112277 \\
\hline Imogiri & Imogiri & 0,86008113 \\
\hline Tirtonirmolo & Kasihan & 0,860081103 \\
\hline
\end{tabular}

Selanjutnya membandingkan tingkat akurasi dan nilai kappa yang dihasilkan oleh metode ANN dengan metode klasifikasi yang berbeda yaitu algoritma SVM, Random Forest dan algoritma Nä̈ve Bayes. Confusion matrix digunakan untuk melakukan proses perbandingan ini. Hasil perbandingan tingkat akurasi dan nilai Kappa pada Tabel 7, menunjukkan bahwa algoritma ANN yang digunakan dalam penelitian ini menempati urutan kedua stelah algoritma Naïve Bayes, dengan tingkat akurasi $95.45 \%$ dan nilai kappa sebesar $87.91 \%$. Hal ini menunjukkan bahwa algoritma ANN cukup akurat digunakan untuk proses klasifikasi dan prediksi dalam menentukan resiko kerusakan lahan akaibat tsunami.

Tabel 7. Perbandingan Tingkat Akurasi dan Nilai Kappa

\begin{tabular}{|l|l|l|}
\hline Algoritma & Akurasi & Kappa \\
\hline Artificial Neural Network & $95.45 \%$ & $87.91 \%$ \\
\hline Support Vector Machine & $88.89 \%$ & $72,31 \%$ \\
\hline Random Forest & $91.43 \%$ & $71.7 \%$ \\
\hline Nä̈ve Bayes & $98 \%$ & $91.17 \%$ \\
\hline
\end{tabular}
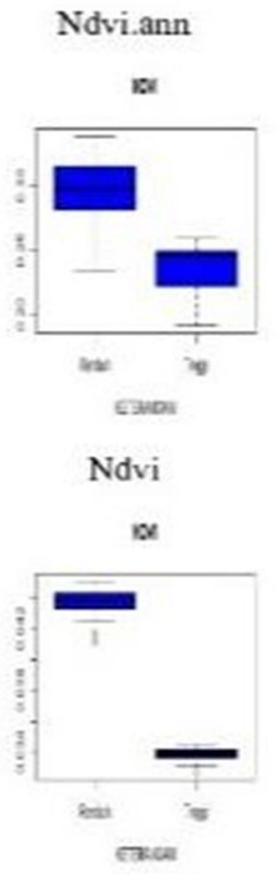

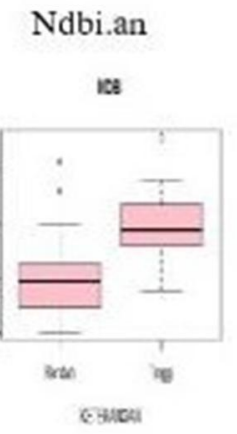

Ndbi

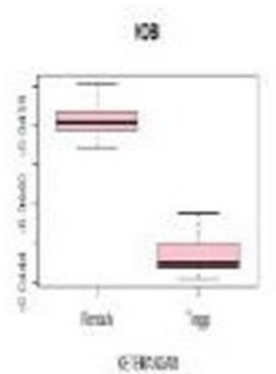

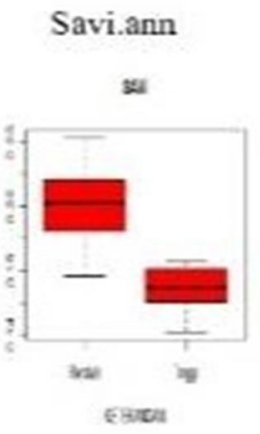

Savi

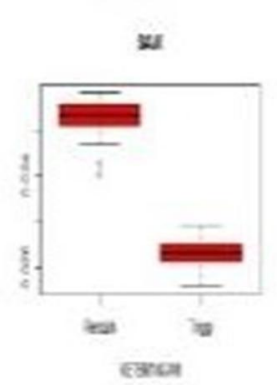

Mndwi.ann

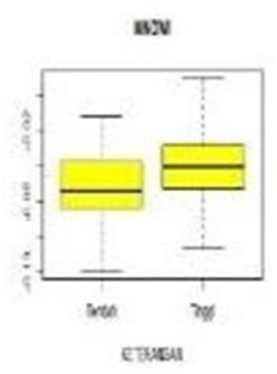

Mndwi

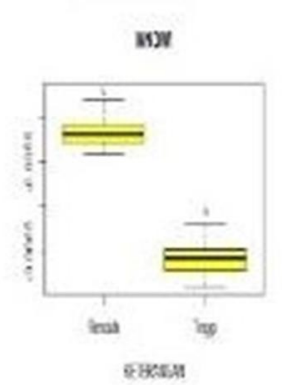

Ndwi.ann

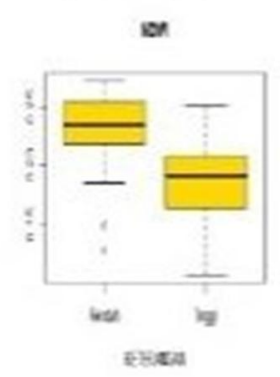

Ndwi

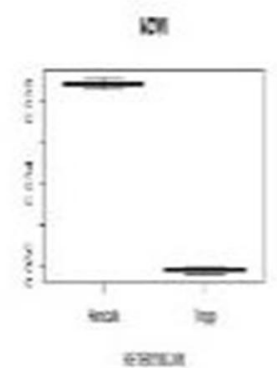

Gambar 6. Analisis Boxplot Antara Resiko Kerusakan Rendah dan Resiko Kerusakan Tinggi 
Gambar 6 menunjukkan bahwa panjang box tiap kelas yaitu potensi kerusakan lahan akibat tsunami rendah dan potensi kerusakan lahan akibat tsunami tinggi memiliki perbedaan yang lumayan besar antara hasil perhitungan indeks vegetasi dan hasil perhitungan menggunakan algoritma ANN.
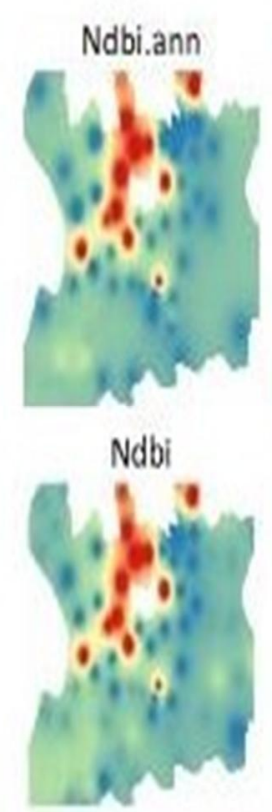

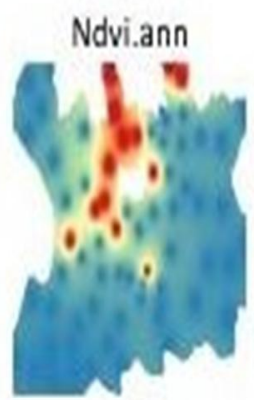

Ndvi

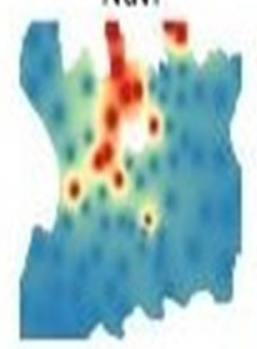

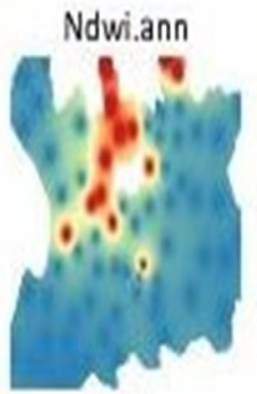

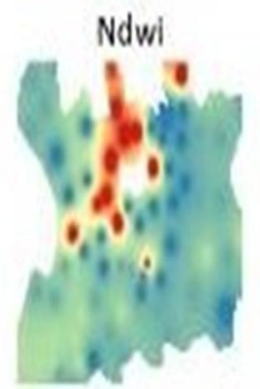

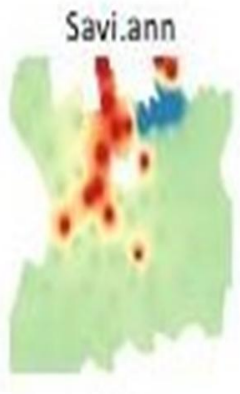

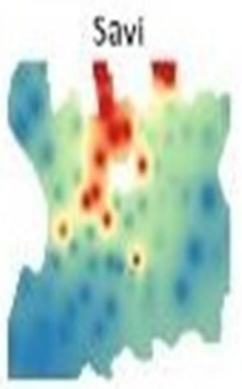

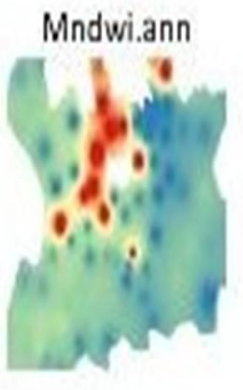

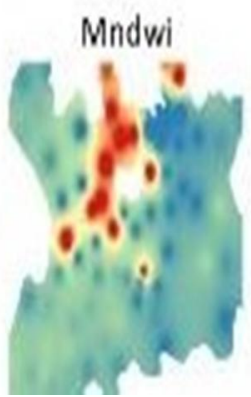

Gambar 7. Gambaran Persebaran Wilayah Resiko Tsunami

Gambar 7 menunjukkan gambaran persebaran wilayah resiko kerusakan lahan akibat tsunami yang memiliki beberapa bagian yang menonjol seperti bagian titik atau gumpalan warna merupakan centroid yang dihasilkan sebelum tahapan IDW. Hasil interpolasi indeks vegetasi dan hasil prediksi kemudian dikelompokkan sesuai warna special dimana resiko kerusakan lahan akibat tsunami rendah memiliki warna hijau, biru muda ke biru tua dan resiko kerusakan lahan akibat tsunami tinggi warna oranye atau merah.

\section{KESIMPULAN}

Berdasarkan hasil dan pembahasan dari penelitian yang telah dilakukan maka dapat disimpulkan beberapa hal, sebagai berikut: 1) Algoritma ANN memberikan hasil yang cukup akurat dengan tingkat akurasi sebesar 95.45\%, dan nilai Kappa sebesar 87.91\%;2) Klasifikasi wilayah resiko kerusakan lahan akibat tsunami menggunakan algoritma ANN memperlihatkan 5 (lima) desa yang memiliki klasifikasi kategori resiko kerusakan lahan paling tinggi yaitu Desa Banguntapan, Desa Bangunjiwo, Desa Ringinharjo, Desa Imogiri, dan Desa Tirtonirmolo.

\section{SARAN}

Saran untuk penelitian lebih lanjut adalah: 1) mengembangkan penelitian ini dengan melakukan eksplorasi data DEM dari STRM agar hasil vegetasi lebih menggambarkan kondisi real; 2) memasukkan perbandingan hasil akurasi dengan metode-metode yang digunakan pada penelitan-penelitian terdahulu; 3) mengeksplorasi berbagai hasil kombinasi dari ANN, dimana 
variasi jumlah neuron pada satu hidden layer dapat digunakan untuk mengobservasi berapa jumlah node yang dibutuhkan pada satu hidden layer; dan 4) menambahkan jumlah hidden layer untuk melihat efek pada tingkat akurasi.

\section{UCAPAN TERIMA KASIH}

Puji Syukur kepada Tuhan Yang Maha Esa atas penyertaanNya sehingga penelitian ini dapat diselesaikan dengan baik. Ucapan terimakasih kepada Dekan FTI Bapak Dr. Wiwin Sulistyo, S.T., M.Kom., Kaprogdi TI Bapak Yeremia Alfa Susetyo, S.Kom., M.Cs., Pembimbing Ibu Magdalena A. Ineke Pakereng, M.Kom., yang memberikan bimbingan dalam melakukan penelitian ini. Secara khusus juga kepada Pusat Studi Simitro dan kepada Bapak Dr. Sri Yulianto Joko Prasetyo, S.Si., M.Kom., dan teman-teman seperjuangan di tempat dimana penulis melakukan penelitian, kepada keluarga yang selalu memberi dukungan doa dan semangat. Semua pihak yang tidak dapat tercantumkan diucapkan terima kasih.

\section{DAFTAR PUSTAKA}

[1] M. R. Amri, 2016, Indeks Risiko Bencana Indonesia, BNPB, Jakarta.

[2] Fajar Ayuningtyas, S. Y. 2020, Pemanfaatan Teknologi Machine Learning Untuk Klasifikasi Wilayah Risiko Kekeringan di Daerah, TRANSFORMTIKA,, 12.

[3] Josua Josen Alexander Limbong. 2020, Analisis Indeks Vegetasi Area Terdampak Banjir Bandang di Kabupaten Jayapura Menggunakan Metode Clustering pada Citra Landsat 8, Indonesia Journal Of Computing and Modeling, 1-6.

[4] Lyonly Evany Tomasoa, S. Y. 2018, Analisis Index Vegetasi Pesisir Pantai Aceh Pasca Tsunami Menggunakan Citra Satelit Landsat 7 dan Landsat 8 Dengan Metode Clustering Algoritma K-Means, Indonesia Journal of Computing and Modeling, 28-35.

[5] Aprizon Putra, T. A. 2017, Pemetaan dan Analisis Perubahan Garis Pantai di Sebagian Pesisir Pantai Pendekatan Metode Normalized Difference Vegetation Index (Ndvi) dan Lyzenga Untuk Pemetaan Sebaran Ekosistem Perairan di Kawasan PesisirTeluk BenoaBali, Geomatika Volume 23 No.2 2017: 87-9, 8.

[6] Mutiah Nurul Handayani, B. S. 2017, Analisis Hubungan Antara Perubahan Suhu Dengan Indeks Kawasan Terbangun Menggunakan Citra Landsat (Studi Kasus: Kota Surakarta), Jurnal Geodesi Undip, 11.

[7] Tania Maria Octarina, I. D. 2019, Penginderaan Jauh Pemrosesan Data Satelit Landsat 8 Untuk Deteksi Genangan. MERPATI VOL. 7, NO. 1 APRIL 2019, 9.

[8] M. Zainul Hasan, I. P. 2019, Monitoring Perubahan Garis Pantai Di Kabupaten Jembrana Tahun 1997 - 2018 Menggunakan Modified Difference Water Index (Mndwi) dan Digital Shoreline Analysis System (DSAS), Jurnal Pendidikan GeografiUndiksha, 93102.

Ellen, et., al [Klasifikasi Resiko Kerusakan Lahan AkibatTsunami Menggunakan Citra Landsat 8 
[9] Riko Yudistira, A. I. 2018, Perubahan Konversi Lahan Menggunakan NDVI, EVI, SAVI, dan PAC pada Citra Landsat 8 (Studi Lasus: Kota Salatiga), Indonesian Journal of Computing and Modeling, 25-30.

[10] Junita Monika Pasaribu, N. S. 2012, Perbandingan Teknik Interpolasi DEM SRTM Dengan Metode Inverse Distance Weighted (IDW), Natural Neighbor Spline, Pusat Pemanfaatan Pengindraan Jauh, LAPAN, 126-139. 